
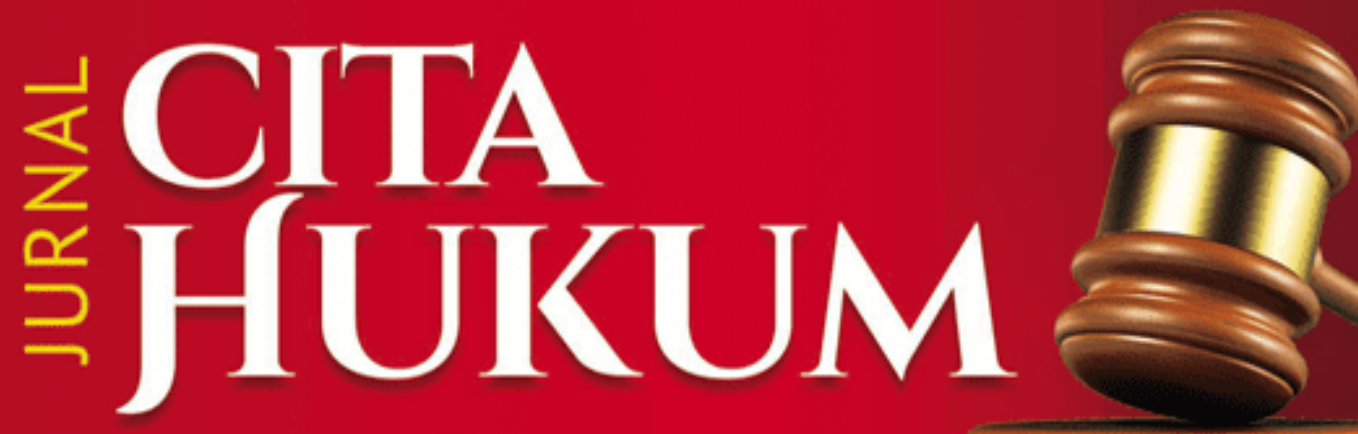

- Penerapan Hukum Jaminan Fidusia Dalam Kontrak Pembiayaan Syariah Muhammad Maksum

- Perlindungan Hukum Terhadap Tenaga Kerja Indonesia (Tinjauan Terhadap UU Nomor 39 Tahun 2004 Tentang Penempatan dan Perlindungan Tenaga Kerja Indonesia) Fatkhul Muin

- Kewenangan Legislasi Dewan Perwakilan Daerah Dalam Reformasi Kelembagaan Perwakilan Pasca Putusan Mahkamah Konstitusi Khamami Zada

- Konsep Pengakuan Bersalah Terdakwa Pada "Jalur Khusus" Menurut RUU KUHAP dan Perbandingannya Dengan Praktek Plea Bargaining Di Beberapa Negara Aby Maulana

- Scope of State Responsibility Against Terrorism in International Law Perspective; Indonesian Cases

Dian Purwaningrum Soemitro \& Indra Wahyu

- Pengendalian Sosial Kejahatan; Suatu Tinjauan Terhadap Masalah Penghukuman Dalam Perspektif Sosiologi Mas Ahmad Yani

- Perubahan Konstitusi dan Reformasi Ketatanegaraan Indonesia Abu Tamrin

- Konsep Perlindungan Hak Cipta Karya Musik Dalam Ranah Hukum Hak Kekayaan Intelektual Dari Tindak Pidana Pembajakan Oksidelfa Yanto 


\section{Jurnal}

\section{CITA HUKUM}

\section{VOL. 3 NO. 1 JUNI 2015}

Diterbitkan oleh Fakultas Syariah dan Hukum Universitas Islam Negeri (UIN) Syarif Hidayatullah Jakarta bekerjasama dengan Pusat Studi Konstitusi dan Legislasi Nasional (POSKO-LEGNAS) UIN

Jakarta. Jurnal Cita Hukum mengkhususkan diri dalam pengkajian Hukum Indonesia dan terbit dua kali dalam satu tahun di setiap bulan Juni dan Desember.

\section{Redaktur Ahli}

Muhammad Atho Mudzhar (UIN Syarif Hidayatullah Jakarta)

Muhammad Amin Suma (UIN Syarif Hidayatullah Jakarta)

Salman Maggalatung (UIN Syarif Hidayatullah Jakarta)

Ahmad Hidayat Buang (University Malaya Malaysia)

Nadirsyah Hosen (Wollongong University Australia)

JM Muslimin (UIN Syarif Hidayatullah Jakarta)

Stephen Koos (Munchen University Germany)

Abdullah Sulaiman (Universitas Trisakti)

Jimly Asshiddiqie (Universitas Indonesia)

Muhammad Munir (IIU Islamabad Pakisatan)

Tim Lindsey (Melbourne University Australia)

Raihanah Azahari (University Malaya Malaysia)

Jaih Mubarok (UIN Sunan Gunung Djati Bandung)

Djawahir Hejazziey (UIN Syarif Hidayatullah Jakarta)

\section{Editor in Chief}

Nur Rohim Yunus

Managing Editor

Muhammad Ishar Helmi

\section{Editors}

Fitria

Indra Rahmatullah

Mara Sutan Rambe

\section{Asisten to The Editors}

Erwin Hikmatiar

\section{Alamat Redaksi}

Fakultas Syariah dan Hukum UIN Syarif Hidayatullah Jakarta

Jl. Ir. H. Juanda 95 Ciputat Jakarta 15412

Telp. (62-21) 74711537, Faks. (62-21) 7491821

Website: www.fsh-uinjkt.net, E-mail: jurnal.citahukum@uinjkt.ac.id

Permalink: http://journal.uinjkt.ac.id/index.php/citahukum 


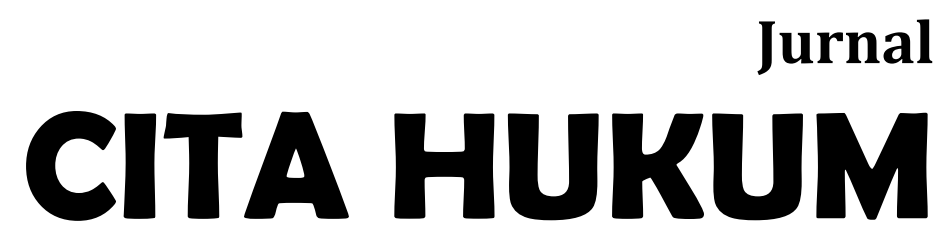

Menyambut baik kontribusi dari para ilmuwan, sarjana, profesional, dan peneliti dalam disiplin ilmu hukum untuk dipublikasi dan disebarluaskan setelah melalui mekanisme seleksi naskah, telaah mitra bebestari, dan proses penyuntingan yang ketat. 


\section{DAFTAR ISI}

1 Penerapan Hukum Jaminan Fidusia Dalam Kontrak Pembiayaan Syariah; Muhammad Maksum

11 Perlindungan Hukum Terhadap Tenaga Kerja Indonesia (Tinjauan Terhadap UU Nomor 39 Tahun 2004 Tentang Penempatan dan Perlindungan Tenaga Kerja Indonesia)

\section{Fathul Muin}

25 Kewenangan Legislasi Dewan Perwakilan Daerah dalam Reformasi Kelembagaan Perwakilan Pasca Putusan Mahkamah Konstitusi Khamami Zada

39 Konsep Pengakuan Bersalah Terdakwa Pada “Jalur Khusus” Menurut RUU KUHAP dan Perbandingannya Dengan Praktek Plea Bargaining di Beberapa Negara

Aby Maulana

67 Scope of State Responsibility Against Terrorism In International Law Perspective; Indonesian Cases

Dian Purwaningrum Soemitro \& Indra Wahyu Pratama

77 Pengendalian Sosial Kejahatan (Suatu Tinjauan Terhadap Masalah Penghukuman Dalam Perspektif Sosiologi)

Mas Ahmad Yani

91 Perubahan Konstitusi dan Reformasi Ketatanegaraan Indonesia Abu Tamrin

99 Konsep Perlindungan Hak Cipta Karya Musik Dalam Ranah Hukum Hak Kekayaan Intelektual Dari Tindak Pidana Pembajakan Oksidelfa Yanto 
115 Tindak Pidana Korupsi (Dugaan Penyalahgunaan Wewenang) Pejabat Publik (Perspektif Undang-Undang Nomor 30 Tahun 2014 Tentang Administrasi Pemerintahan)

Fathudin

133 Perlindungan Hukum Bagi Investor Terhadap Praktik Kejahatan Insider Trading Pada Pasar Modal Di Indonesia

Fadilah Haidar

153 Penyalahgunaan Perjanjian Lisensi Merek Dalam Praktek Bisnis Hak Atas Kekayaan Intelektual Ida Rofida

169 Persamaan Unsur Pokok Pada Suatu Merek Terkenal (Analisis Putusan MA Nomor 162 k/pdt.sus-hki/2014)

Muhammad Dandi Pahusa 


\title{
Perubahan Konstitusi Dan Reformasi Ketatanegaraan Indonesia*
}

\author{
Abu Tamrin \\ Fakultas Syariah dan Hukum UIN Jakarta \\ Jl. Ir. H. Juanda No. 95 Ciputat Tangsel \\ E-mail: abutamrin36@yahoo.com
}

\begin{abstract}
Constitutional Reform and Indonesian State Reformation. Constitution, according to Constitutional Court Experts is a formal document as a result of political battle in the past. In New Order Era, Constitution of 1945 was sacred so the Assembly of People Deliberative could not amend the Constitution. In Reformation Era, there has been four times amendment in which the supremacy belongs to People and conducted according to the Constitution. In addition, the new state institution has been created such as Constitutional Court and the other hand, the other state institution has been liquided named House of Supreme Consultative.. These amendments lead to the Indonesian Constitutional Reforms.
\end{abstract}

Keywords: Constitution, Reformation, Statehood

\begin{abstract}
Abstrak: Perubahan Konstitusi dan Reformasi Ketatanegaraan Indonesia. Konstitusi menurut Pakar Hukum Tata Negara berisi Hukum dasar tertulis. Undang-undang Dasar 1945, sebagai Konstitusi adalah dokumen formal yang merupakan hasil perjuangan politik bangsa di waktu lampau. Di era orde baru Undang-Undang Dasar 1945 “disakralkan" sehingga Majelis Permusyawaratan Rakyat RI di era orde baru tidak dapat mengubahnya. Di era reformasi dilakukan empat kali perubahan terhadap UUD 1945. Salah satunya Pasal 1 ayat (2) perubahan pertama Undang-undang Dasar 1945, yaitu kedaulatan ada di tangan rakyat dan dilakukan menurut Undang-undang Dasar. Selain itu ada lembaga negara baru yang dibentuk, salah satunya Mahkamah Konstitusi RI dan ada lembaga tinggi negara yang dihapus, yaitu Dewan Pertimbangan Agung RI. Dengan adanya perubahan Undang-Undang Dasar 1945, maka terjadi reformasi ketatanegaraan Indonesia.
\end{abstract}

Kata Kunci: Konstitusi, Reformasi, Ketatanegaraan.

DOI: $\underline{10.15408 / \text { jch.v2i1.1843 }}$ 


\section{Abu Tamrin}

\section{Pendahuluan}

Makna dan pengertian konstitusi dapat dikaji dari berbagai disiplin ilmu pengetahuan antara lain: dari disiplin hukum dan politik. Menurut K.C. Wheare yang merupakan pakar konstitusi menjelaskan kata konstitusi dalam dua arti: ${ }^{1}$ Pertama dalam arti luas "konstitusi" digunakan untuk menggambarkan keseluruhan sistem pemerintahan suatu negara, kumpulan aturan yang membentuk dan mengatur pemerintahan.Aturan tersebut ada yang bersifat hukum yang mana pengadilan mengakui dan menerapkan aturan-aturan itu dan ada pula yang bersifat nonhukum berbentuk usages, understanding, dancustoms.Kedua dalam arti sempit "konstitusi" merupakan kumpulan aturan penyelenggara negara yang dimuat dalam dokumen. Istilah konstitusi berasal dari "constituter" (bahasa Perancis) yang berarti membentuk. Pemakaian istilah konstitusi yang dimaksudkan ialah pembentukan suatu negara atau menyusun dan menyatakan suatu negara. ${ }^{2}$

Pakar Hukum Tata Negara menyamakan pengertian konstitusi dengan Undang-undang Dasar. Adapun alasannya ialah keduanya berisi hukum dasar yang tertulis. Kalau kita kaji secara mendalam ada perbedaan konstitusi dengan Undangundang Dasar. Konstitusi berisi hukum dasar tertulis dan hukum dasar tidak tertulis, sedangkan Undang-undang Dasar hanya berisi hukum dasar tertulis. Tidak ada negara di dunia yang tidak mempunyai konstitusi termasuk Indonesia. Sebaliknya tidak setiap negara di dunia mempunyai Undang-undang Dasar, contoh Inggris tidak mempunyai Undang-undang Dasar walaupun Inggris merupakan pendukung demokrasi. Dalam tulisan ini akan dibahas lebih lanjut tentang materi konstitusi/Undang-undang Dasar 1945 secara umum dan perubahan konstitusi Undang-undang Dasar 1945.

\section{Pembahasan}

Hene van Maarseven dan Gerk van der Rang dalam sebuah studi terhadap konstitusi-konstitusi di dunia dan dituangkan dalam buku dengan judul Write Constitution antara lain mengatakan: 1) constitution as a means of forming the states on practical and legal system. 2) constitution a national document and as a birth certificate and as a sign of adulthood and independence. ${ }^{3}$ Dari pemaparan kedua pakar konstitusi Belanda dapat dipahami konstitusi sebagai alat untuk membentuk sistem politik dan sistem hukum negaranya sendiri dan sebagai dokumen nasional.

Selanjutnya A.A.K. Struycler, Undang-undang Dasar (Gronwert) sebagai konstitusi tertulis merupakan sebuah dokumen formal yang berisi:4 1). Hasil perjuangan politik bangsa di waktu lampau. 2). Tingkat-tingkat tertinggi perkembangan ketatanegaraan bangsa. 3). Pandangan tokoh-tokoh bangsa yang hendak diwujudkan baik waktu sekarang maupun untuk masa yang akan datang. 4).

\footnotetext{
${ }^{1}$ K.C. Wheare, Modern Constituion, London: Oxford University Press, 1966.

2 Wirjono Prodjodikoro, Asas-asas Hukum Tata Negara Indonesia, Jakarta: Penerbit Dian Rakyat, 1989, h. 10 .

${ }^{3}$ Sri Soemantri M, Fungsi Konstitusi Dalam Pembatasan Kekuasaan, dikutip di Jurnal Hukum No. 6 vol. 3, 1996, h.4.

${ }^{4}$ Op.Cit, h.2.
}

92 - Jurnal Cita Hukum. Vol. 3 No. 1 Juni 2015. ISSN: 2356-1440. 
Suatu keinginan dengan nuansa perkembangan kehidupan ketatanegaraan bangsa sesuai kehendak yang dipimpin.

Konstitusi/Undang-undang Dasar 1945 merupakan dokumen formal yang merupakan hasil perjuangan politik bangsa di waktu lampau. Idealnya dokumen tersebut ditetapkan sebelum Indonesia memproklamirkan kemerdekaan pada 17 Agustus 1945, namun dokumen tersebut baru ditetapkan keesokan harinya setelah Indonesia Merdeka yaitu pada tanggal 18 Agustus 1945.Adapun yang menetapkan konstitusi/Undang-undang Dasar 1945 adalah PPKI (Panitia Persiapan Kemerdekaan Indonesia).

Materi muatan konstitusi/Undang-undang Dasar dalam rangka untuk membatasi kekuasaan dalam negara sekurang-kurangnya berisi: ${ }^{5} 1$ ). Jaminan adanya perlindungan Hak Asasi Manusia. 2). Susunan kekuasaan suatu negara yang mendasar. 3). Pembagian dan pembatasan tugas-tugas ketatanegaraan yang juga mendasar.

Undang-undang Dasar 1945 menurut penulis merupakan Undang-undang Dasar yang singkat karena hanya memuat 37 Pasal, 4 Aturan Peralihan dan 2 Aturan Tambahan. Walaupun demikian bukan berarti Undang-undang Dasar 1945 tidak dapat dirubah karena moment opname di bidang politik dan ekonomi berbeda antara waktu Undang-undang Dasar 1945 ditetapkan dengan waktu setelah lebih 50 tahun Indonesia merdeka. Sebenarnya di dalam Undang-undang Dasar 1945 sebagai dasar hukum untuk merubah Undang-undang Dasar 1945. Di dalam Pasal 37 ayat (1) Undang-undang Dasar 1945 sebelum perubahan dijelaskan: Untuk mengubah Undang-undang Dasar sekurang-kurangnya 2/3 dari pada jumlah anggota Majelis Permusyawaratan Rakyat harus hadir. Kemudian di dalam Pasal 37 ayat (2) Undangundang Dasar sebelum perubahan dijelaskan: Putusan diambil dengan sekurangkurangnya 2/3 dari pada jumlah anggota yang hadir. Menurut penulis walaupun ada dasar hukum di dalam Undang-undang Dasar 1945 untuk mengubah Undangundang Dasar 1945, namun tidak ada political will dari Lembaga Tertinggi Majelis Permusyawaratan Rakyat RI.

Di awal era reformasi pada tahun 1998 salah satu tuntutan dari berbagai pihak adalah dilakukan perubahan Undang-undang Dasar 1945. Pada waktu era orde baru Undang-undang Dasar 1945 "disakralkan". Salah satu "berkah reformasi" adalah dilakukan perubahan Undang-undang Dasar 1945. Adapun alasan-alasan diadakan perubahan Undang-undang Dasar 1945 yaitu:

Pertama; Secara Filosofis. Yaitu: 1). Undang-undang Dasar 1945 moment opname dari berbagai kekuatan politik dan ekonomi yang demikian pada saat dirumuskan Undang-undang Dasar 1945. Setelah lebih dari 50 tahun tentu terdapat perubahan baik di tingkat pusat maupun di tingkat daerah. Hal ini belum tercantum di dalam Undang-Undang Dasar 1945. 2). Undang-undang Dasar 1945 disusun oleh manusia yang tidak sampai kepada kesempurnaan.

\footnotetext{
5 Sri Soemantri M, Hukum Tata Negara Indonesia, Pemikiran dan Pandangan, Bandung: PT Remaja Rosda Karya: 2014, h. 20.
} 


\section{Abu Tamrin}

Kedua; Secara Historis. Dari semula penyusun Undang-undang Dasar 1945 bersifat sementara. Hal ini dinyatakan oleh Ir. Soekarno (Ketua PPKI) dalam rapat pertama tanggal 18 Agustus 1945: Undang-undang Dasar yang kita buat adalah Undang-undang Dasar kilat. Nanti kalau kita telah bernegara dalam suasana lebih tentram kita tentu akan mengumpulkan Majelis Permusyawaratan Rakyat RI yang dapat membuat Undang-undang Dasar yang lebih lengkap dan lebih sempurna.

Ketiga; Secara Yuridis. Para perumus Undang-undang Dasar 1945 telah menunjukan kearifan bahwa apa yang mereka lakukan ketika Undang-undang Dasar 1945 disusun akan berbeda kondisinya dengan masa yang akan datang dan suatu saat akan mengalami perubahan.

Keempat; Secara Substantif. Undang-undang Dasar 1945 banyak sekali mengandung kelemahan antara lain: 1). Kekuasaan eksekutif terlalu besar tanpa disertai checks and balances. 2). Rumusan Undang-undang Dasar 1945 sebagian besar bersifat sangat sederhana, umum atau tidak jelas sehingga menimbulkan multi tafsir. 3). Unsur-unsur konstitusionalisme tidak dielaborasi secara memadai dalam Undangundang Dasar 1945. 4). Terlalu menekankan pada semangat penyelenggara negara. 5). Undang-undang Dasar 1945 memberikan atribusi kewenangan terlalu besar kepada presiden untuk mengatur berbagai hal penting kepada undang-undang. 6). Banyak materi muatan yang penting justru diatur di dalam penjelasan Undang-undang Dasar 1945 dan tidak tercantum di dalam Pasal Undang-undang Dasar 1945. 7). Status materi penjelasan Undang-undang Dasar 1945 terpisah atau menyatu dengan pasal Undang-undang Dasar 1945.

Kelima; Secara Politik. Salah satu kesepakatan MPR RI adalah untuk pembenahan sistem dan struktur ketatanegaraan. Alasan perubahan Undang-undang Dasar 1945 menurut Maria Farida Indrati Soeprapto:

1). Tuntutan reformasi. Pada tahun 1998 di Negara Republik Indonesia terjadi demonstrasi dari berbagai kalangan masyarakat termasuk mahasiswa untuk "menurunkan" Presiden RI yang telah berkuasa selama sekitar 30 Tahun. Pada era Orde Baru dalam perubahan Undang-Undang Dasar 1945 terhambat oleh ketentuan bahwa MPR RI tidak akan mengubah Undang-undang Dasar 1945.

2). Pasal-pasal Undang-Undang Dasar 1945 yang multi tafsir. Dengan adanya pasal-pasal Undang-undang 1945 yang multi tafsir, dalam praktik ketetanegaraan RI menimbulkan ketidakpastian. Penafsiran pasal Undang-undang Dasar 1945 yang dianggap benar adalah tafsir Pemerintah (Presiden RI). Salah satu contoh adalah ketentuan Pasal 7 Undang-undang Dasar 1945: Presiden dan Wakil Presiden memegang jabatannya selama 5 tahun dan sesudahnya dapat dipilih kembali. Tafsir Pemerintah (Presiden RI) adalah: Presiden dan Wakil Presiden dapat dipilih lebih 2 kali periode asal masa jabatan Presiden dan Wakil Presiden 5 Tahun dalam 1 periode dan dipilih oleh Majelis Permusyawaratan RI dengan suara terbanyak.

3). Tidak ada checks and balances terhadap organ negara. Paradigma sebelum perubahan Undang-undang Dasar 1945 adalah Majelis Permusyawaratan RI sebagai pelaksana dan pemegang kedaulatan rakyat, Lembaga tersebut sebagai lembaga tertinggi negara yang membawahi lembaga tinggi negara yang diatur di dalam Undang-undang Dasar 1945. 
4). Tidak banyak memuat Hak Asasi Manusia. Ada 2 kelompok yang berbeda pendapat di persidangan BPUPKI yaitu: Soekarno dan Soepomo di satu pihak dan Muhammad Hatta dan Muhammad Yamin di pihak lain. Soekarno dan Soepomo berpendapat: Tidak menyetujui pasal Hak Asasi Manusia dimasukkan di dalam Undang-Undang Dasar 1945. Adapun alasannya adalah Negara Indonesia yang didirikan adalah negara gotong royong menolak individualisme. Selanjutnya Muhammad Hatta dan Muhammad Yamin berpendapat: Mengusulkan agar pasalpasal Hak Asasi Manusia dimasukkan di dalam Undang-undang Dasar 1945 agar Pemerintah tidak berlaku sewenang-wenang. Dengan adanya 2 kelompok yang berbeda pendapat, maka ditempuh jalan kompromi, pengaturan Hak Asasi Manusia diatur di dalam Undang-Undang Dasar 1945 secara terbatas.

5). Tidak merupakan living constitution. Dalam kenyataannya selama pemberlakuan Undang-undang Dasar 1945 tidak merupakan living constitution atau merupakan konstitusi yang hidup.

Dalam rangka untuk mereformasi ketatanegaraan Republik Indonesia maka tujuan perubahan Undang-Undang Dasar 1945 adalah:6 1). Menyempurnakan aturan dasar tatanan negara dalam mencapai tujuan nasional yang tertuang dalam pembukaan Undang-undang Dasar 1945 dan memperkokoh Negara Kesatuan RI berdasarkan Pancasila. 2). Menyempurnakan aturan dasar mengenai jaminan dan pelaksanaan kedaulatan rakyat serta memperluas partisipasi masyarakat agar sesuai dengan perkembangan paham demokrasi. 3). Menyempurnakan aturan dasar mengenai jaminan dan perkembangan Hak Asasi Manusia agar sesuai dengan perkembangan paham Hak Asasi Manusia dan peradaban umat manusia. 4). Menyelenggarakan aturan dasar penyelenggaraan negara secara demokratis dan modern antara lain melalui: (a). Pembagian kekuasaan yang lebih tegas, (b). Sistem saling mengawasi dan saling mengimbangi (checks and balances) yang lebih ketat dan transparan. (c). Pembentukan lembaga negara yang baru untuk mengakomodasi perkembangan kebutuhan bangsa. 5). Menyempurnakan aturan dasar negara mengenai jaminan konstitusional dan kewajiban negara mengenai jaminan sosial mencerdaskan kehidupan bangsa, menciptakan solidaritas kehidupan bermasyarakat berbangsa dan bernegara sesuai dengan hakikat dan martabat kemanusiaan dalam mewujudkan negara sejahtera. 6). Melengkapi aturan dasar yang penting dalam menyelenggarakan negara bagi eksistensi negara dan perjuangan negara mewujudkan demokrasi seperti pengaturan wilayah dan pemilihan umum. 7). Menyempurnakan aturan dasar bernegara sesuai dengan perkembangan bangsa dan negara Indonesia dewasa ini sekaligus mengakomodasi kecenderungan untuk kurun waktu yang akan datang.

Berikut ini penulis paparkan Pasal Undang-undang Dasar 1945 yang dirubah dan ditambah:

Pasal 1 ayat (2) Undang-undang Dasar 1945 sebelum perubahan: Kedaulatan ada di tangan rakyat dan dilaksanakan sepenuhnya oleh Majelis Permusyawaratan

6Jimly Assidiqy dkk, Gagasan Amandemen UUD 1945 dan Pemilihan Presiden Secara Langsung, Sekjen \& Kepaniteraan NKRI, 2000, h. xvi. 


\section{Abu Tamrin}

Rakyat. Majelis Permusyawaratan Rakyat sebelum perubahan Undang-undang Dasar 1945 sebagai Lembaga Negara Tertinggi yang anggotanya sebagai penjelmaan rakyat dan sebagai pelaksanaan kedaulatan rakyat, sehingga Lembaga Tertinggi Negara tersebut membawahi Lembaga Tinggi Negara Presiden, DPR, DPA, BPK dan MA.

Dengan adanya perubahan ketiga Pasal 1 ayat (2) Undang-undang Dasar 1945: Kedaulatan di tangan rakyat dan dilakukan menurut Undang-undang Dasar. Majelis Permusyawaratan Rakyat setelah ada perubahan ketiga Pasal 1 ayat (2) Undang-undang Dasar 1945 bukan merupakan Lembaga Tertinggi Negara, melainkan hanya sebagai Lembaga Negara yang sederajat dengan Presiden, DPR, DPD dan lainlain. Majelis Permusyawaratan Rakyat RI bukan satu-satunya lembaga negara sebagai pelaksanaan kedaulatan rakyat namun setiap lembaga negara sebagai pelaksana kedaulatan rakyat sesuai dengan kewenangan masing-masing.

Dengan perubahan ketiga Pasal 1 ayat (3) Undang-undang Dasar 1945 maka menurut penulis mempertegas bahwa Indonesia adalah negara hukum. Dikatakan mempertegas karena sebelum Perubahan Undang-undang Dasar 1945 yaitu di dalam penjelasan umum Undang-undang Dasar 1945 dijelaskan bahwa Negara Republik Indonesia adalah negara hukum.

Sebelum Undang-undang Dasar 1945 banyak hak prerogratif presiden artinya hak yang istimewa yang dimiliki presiden tanpa campur tangan atau pertimbangan/masukan lembaga tinggi lain. Salah satu kekuasaan Presiden RI adalah kekuasan yudikatif, yaitu dalam hal Presiden RI memberi grasi, amnesti, abolisi dan rehabilitasi. Setelah Undang-undang Dasar 1945 dirubah, maka Presiden RI memberikan grasi, amnesti, abolisi dan rehabilitasi bukan menjadi hak prerogratif Presiden. Hal ini dijelaskan di dalam Pasal 14 ayat (1) perubahan pertama Undangundang Dasar 1945: Presiden memberi grasi dan rehabilitasi dengan memperhatikan pertimbangan Mahkamah Agung. Dalam pasal 14 ayat (2) perubahan pertama Undang-undang Dasar 1945: Presiden memberi amnesti dan rehabilitasi dengan memperhatikan pertimbangan Dewan Perwakilan Rakyat.

Dalam rangka mempertegas sistem pemerintahan presidensial di era reformasi, maka ada penambahan Pasal 6 Undang-undang Dasar 1945 yang mengatur Pemilihan Presiden dan Wakil Presidensecara langsung, yaitu diatur di dalam Pasal 6 A ayat (1) perubahan ketiga Undang-undang Dasar 1945: Presiden dan Wakil Presiden dipilih dalam satu pasangan secara langsung oleh rakyat.Untuk memperjelas pengaturan Hak Asasi Manusia ada penambahan Pasal 28 Undang-undang Dasar 1945, salah satunya diatur di dalam Pasal 28 A perubahan kedua Undang-undang Dasar 1945: Setiap orang berhak untuk hidup serta berhak untuk mempertahankan kehidupannya.

Dengan alasan adanya salah satu asas peraturan perundang-undangan: Bahwa undang-undang tidak dapat diganggu gugat. Walaupun ada pasal, ayat, fraseatau bagian undang-undang yang bertentangan dengan Undang-undang Dasar 1945, namun Mahkamah Agung RI tidak dapat melakukan pengujian Undangundang terhadap Undang-undang Dasar1945 karena menurut Undang-undang yang berlaku Mahkamah Agung RI hanya dapat melakukan pengujian peraturan perundang-undangan yang hirearkinya di bawah Undang-undang.Kemudian adanya 
studi banding anggota Majelis Permusyawaratan Rakyat RI ke luar negeri maka dibentuk Mahkamah Konstitusi RI sebagai pelaksana kekuasaan kehakiman.Hal ini dijelaskan di dalam Pasal 24 ayat (2) Perubahan Ketiga Undang-undang Dasar 1945: Kekuasaan Kehakiman dilakukan oleh sebuah Mahkamah Agung dan badan-badan peradilan yang berada di bawahnya dalam lingkungan peradilan umum, lingkungan peradilan agama, lingkungan peradilan militer, lingkungan peradilan tata usaha negara dan oleh sebuah Mahkamah Konstitusi.

Adapun tugas dan kewajiban Mahkamah Konstitusi RI diatur di dalam Pasal 24 C ayat (1) dan ayat (2) Undang-undang Dasar 1945 perubahan ketiga.Pasal 24 C ayat (1) Undang-undang Dasar menjelaskan: Mahkamah Konstitusi berwenang mengadili pada tingkat pertama dan terakhir yang putusannya bersifat final untuk menguji Undang-undang terhadap Undang-undang Dasar, memutus sengketa kewenangan Lembaga Negara yang kewenangannya diberikan oleh Undang-undang Dasar, memutus pembubaran partai politik dan memutus perselisihan tentang hasil pemilihan umum. Selanjutnya di dalam Pasal $24 \mathrm{C}$ ayat (2) dijelaskan: Mahkamah Konstitusi wajib memberikan putusan atas pendapat Dewan Perwakilan Rakyat RI mengenai dugaan pelanggaran oleh Presiden dan/atau Wakil Presiden menurut Undang-undang Dasar 1945. Dengan alasan tidak optimal pengawasan internal hakim oleh Mahkamah Agung RI, maka dibentuk Komisi Yudisial RI yang diatur di dalam Pasal 24 B Perubahan Ketiga Undang-undang Dasar 1945. Di dalam pasal 24 C ayat (1) Undang-undang Dasar 1945 dijelaskan: Komisi Yudisial bersifat mandiri yang berwenang mengusulkan pengangkatan hakim agung dan mempunyai kewenangan lain dalam rangka menjaga dan menegakkan kehormatan, keluhuran martabat, serta perilaku hakim.

Salah satu Lembaga Tinggi Negara yang dihapus di era reformasi, yaitu Dewan Pertimbangan Agung RI yang diatur di dalam Pasal 16 Perubahan Keempat Undang-undang Dasar 1945. Menurut penulis ada 2 alasan Dewan Pertimbangan Agung RI dihapus di era reformasi, yaitu: Pertama menurut Majelis Permusyawaratan Rakyat RI dilihat dari struktur ketatanegaran RI rancu karena sebagai Dewan Penasehat Presiden RI namun kedudukannya sederajat dengan Presiden RI. Kedua dalam memberikan jawaban, nasehat, dan pertimbangan kepada Presiden RI dilihat segi kuantitas adalah banyak namun dilihat dari segi kualitas menurut Majelis Permusyawaratan Rakyat RI amat rendah.

Kesepakatan PAH I Majelis Permusyawaratan Rakyat RI dalam melakukan perubahan Undang-undang Dasar 1945:

Pertama; Tidak mengubah Pembukaan Undang-undang Dasar 1945. Menurut Maria Farida Indrati Soeprapto, alasan tidak dirubah pembukaan Undangundang Dasar 1945 terdapat: nilai agama, nilai adat dan nilai gotong royong. Selain itu di dalam pembukaan Undang-undang Dasar 1945 terdapatnorma fundamental norm, cita hukum pancasila. Kalau pembukaan Undang-undang Dasar 1945 dirubah berarti merubah Pancasila.

Kedua; Tetap mempertahankan Negara Kesatuan Republik Indonesia. Founding fathers (pendiri negara RI) sepakat: Bentuk negara kita adalah negara kesatuan. Undang-undang Nomor 22 Tahun 1999 dan penggantinya Undang-undang 


\section{Abu Tamrin}

Nomor 32 Tahun 2004 dan Undang-undang Nomor 23 Tahun 2014 tidak mengarah ke federasi. Pelaksanaan Pemerintah Daerah dan otonomi daerah menurut peraturan perundang-undanganyang berlaku masih dalam kerangka kesatuan RI.

Ketiga; Mempertegas sistem pemerintahan presidensil. Menurut Maria Farida Indrati Soeprapto untuk mempertegas sistem pemerintahan presidensil: Adanya Pemilu Presiden dan Wakil Presiden secara langsung. Ada batasan masa jabatan Presiden dan Wakil Presiden maksimal 2 periode pada jabatan yang sama.

Keempat; Meniadakan penjelasan Undang-undang Dasar 1945. Penjelasan Undang-undang Dasar 1945 yang memuat hal-hal yang normatif dimasukkan ke dalam batang tubuh Undang-undang Dasar 1945.Menurut Maria Farida Indrati Soeprapto penjelasan Undang-undang Dasar 1945 merupakan interpretasi autentik menyatu dengan Pasal Undang-undang Dasar 1945.Penjelasan Undang-undang Dasar 1945 boleh dicabut dari sejarah hukum.

Kelima; Perubahan Undang-undang Dasar 1945 dilakukan dengan cara "addendum". Dengan adanya perubahan Undang-undang Dasar 1945 secara addendum maka tidak ada istilah Undang-undang Dasar asli dan Undang-undang Dasar baru karena pembukuan Undang-undang Dasar 1945 sebelum dan sesudah perubahan Undang-undang Dasar 1945 menyatu.

\section{Penutup}

Setelah diuraikan di dalam pembahasan dapat disimpulkan sebagai berikut:

Pertama; Sebetulnya ada dasar hukum yaitu di dalam Pasal 37 Undangundang Dasar 1945 sebelum perubahan untuk merubah Undang-undang Dasar 1945 namun tidak ada political will oleh Lembaga Negara Tertinggi Majelis Permusyawaratan Rakyat RI untuk mengubah Undang-undang Dasar 1945.

Kedua; Untuk melaksanakan salah satu tuntutan lapisan masyarakat maka di awal era reformasi dilakukan perubahan Undang-undang Dasar 1945. Dengan adanya perubahan Undang-undang Dasar 1945 maka terjadi reformasi ketatanegaraan RI.

\section{Pustaka Acuan}

Jimly Assidiqy dkk, Gagasan Amandemen UUD 1945 dan Pemilihan Presiden secara langsung, Sekjen \& Kepaniteraan NKRI, 2000.

K.C. Wheare, Modern Constitution, Oxford University Press, London, 1966.

Sri Soemantri M, Hukum Tata Negara Indonesia, Pemikiran dan Pandangan, Bandung: Penerbit PT Remaja Rosda Karya, 2014.

Wirjono Prodjodikoro, Asas-asas Hukum Tata Negara Indonesia, Jakarta: Penerbit Dian Rakyat, 1989.

Undang-Undang Dasar 1945.

Undang-Undang Nomor 22 Tahun 1999 Tentang Pemerintahan Daerah.

Undang-Undang Nomor 32 Tahun 2004 Tentang Pemerintahan Daerah.

Undang-Undang Nomor 23 Tahun 2014 Tentang Pemerintahan Daerah.

98 - Jurnal Cita Hukum. Vol. 3 No. 1 Juni 2015. ISSN: 2356-1440. 
